\title{
POLA ASUH ORANG TUA PENGGANTI PADA ANAK USIA DINI
}

Pola asuh orang tua dalam menanamkan kemandirian dan kedisiplinan pada anak usia dini dapat menggiring anak untuk memiliki masa depan yang lebih baik dan bernilai positif. Beberapa fenomena yang sering terjadi di masyarakat saat ini adalah ketidak harmonisan dalam rumah tangga yang berujung pada pertengkaran dan perceraian orang tua yang akan memengaruhi pengasuhan dan pembentukan karakter anak. Keluarga yang menerapkan pola asuh yang positif mampu membawa anak lebih hidup lebih mandiri dan disiplin.

Mendidik dan membimbing anak merupakan suatu kewajiban bagi setiap orang tua. Orang tua harus mampu menerapkan pendidikan yang membuat anak mempunyai prinsip untuk menjalankan hidupnya dengan positif, baik dari agama, pergaulan maupun lingkungan, sehingga mampu membentuk mereka menjadi anak yang mandiri dan disiplin sertabermanfaat.

Namun masih banyak orang tua baik ayah maupun ibu menganggap bahwa tanggung jawab terbesar dalam pengasuhan adalah dengan memenuhi kebutuhan dan memberi fasilitas yang cukup bagi anak, sehingga yang lakukan oleh orang tua adalah mencukupi segala kebutuhan mereka dengan bekerja sepanjang hari atau bekerja di luar negeri (migrant worker) sehingga menyerahkan pengasuhan kepada keluarga. Oleh sebab itu, pengasuhan anak diserahkan kepada kerabat dekat, terutama oleh orang tua ibu atau orang tua ayah yang disebut sebagai nenek atau kakek (grandparents). Fenomena ini menjadikan orang tua tidak dapat terlibat langsung dalam proses pengasuhan anak.

Ketegasan orangtua pengganti (grandparenting) bukan mengekang ruang gerak anak, tetapi untuk mengatur anak agar disiplin dan bisa bertanggungjawab terhadap orang tua dan dirinya sendiri. Pengasuhan orangtua pengganti (grandparents) tidak terlepas dari pandangan hidup wilayah dan budaya setempat dimana menurut kakek dan nenek (grandparents) bahwa mengasuh dengan mempertahankan pola-pola lama justru membuat anak lebih berhasil. Sejalan dengan pendapat Santrock bahwa pengasuhan dapat dipengaruhi budaya, etnisitas, dan status sosial ekonomi. Budaya memiliki nilai-nilai yang digunakan sebagai tolok ukur yang menentukan

Buku ini mendeskripsikan bentuk pengasuhan kakek dan nenek (grandparents) dalam menanamkan kemandirian dan kedisiplinan anak usia 4-6 tahun, peran kakek dan nenek (grandparents) dalam menanamkan kemandirian dan kedisplinan pada anak usia 46 tahun, proses pembentukan kemandirian dan kedisiplinan pada anak usia 4-6 tahun yang di asuh oleh kakek dan nenek dan pola asuh budaya setempat dalam menanamkan kemandirian dan kedisplinan anak usia 4-6 tahun.

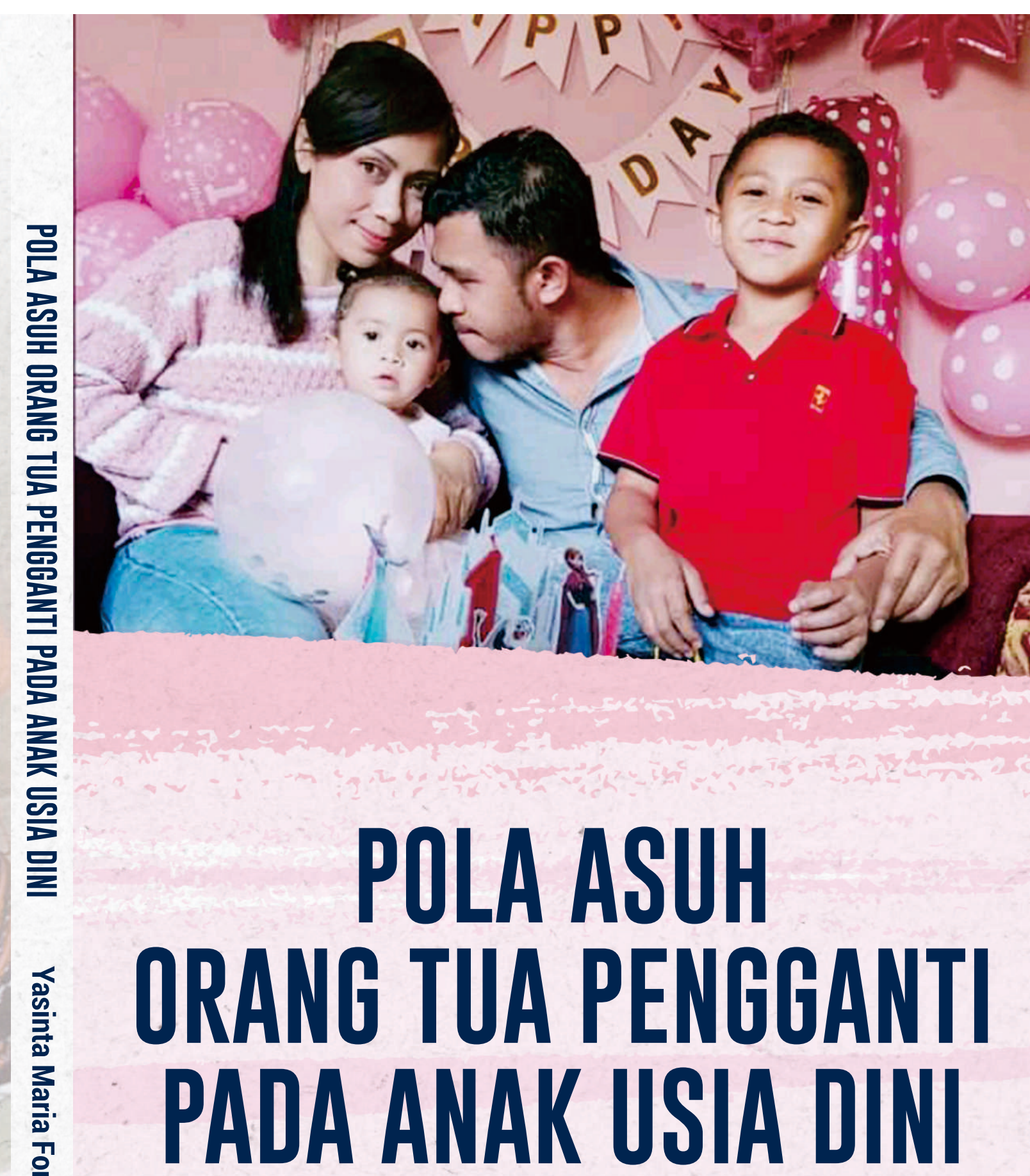

Yasinta Maria Fono, M.Pd.
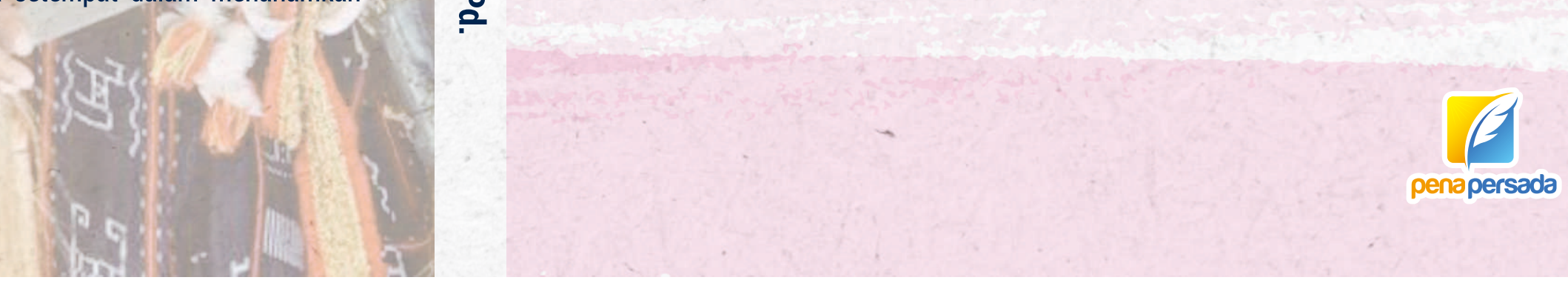


\section{POLA ASUH ORANG TUA PENGGANTI PADA ANAK USIA DINI}

Yasinta Maria Fono, M.Pd.

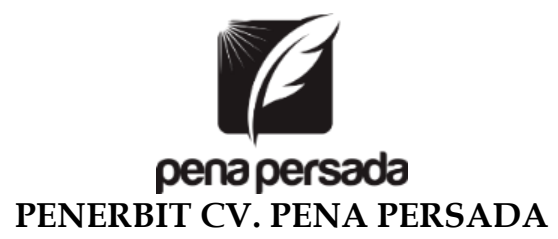




\title{
POLA ASUH ORANG TUA PENGGANTI PADA ANAK USIA DINI
}

Penulis:

Yasinta Maria Fono, M.Pd.

ISBN: 978-623-315-403-1

\author{
Editor: \\ Rusfik Yulli Anur Wati \\ Design Cover: \\ Retnani Nur Briliant \\ Layout: \\ Nisa Falahia
}

\section{Penerbit CV. Pena Persada \\ Redaksi:}

Jl. Gerilya No. 292 Purwokerto Selatan, Kab. Banyumas

Jawa Tengah

Email: penerbit.penapersada@gmail.com

Website: penapersada.com Phone: (0281) 7771388

Anggota IKAPI

All right reserved

Cetakan pertama: 2021

Hak Cipta dilindungi oleh undang-undang. Dilarang memperbanyak karya tulis ini dalam bentuk apapun tanpa izin penerbit 


\section{KATA PENGANTAR}

Segala puji senantiasa kita panjatkan kehadirat Tuhan Yang Maha Kuasa, atas segala rahmat dan karunia-Nya, akhirnya penulis dapat menyelesaikan penyusunan buku yang berjudul "Pola Asuh Orang Tua Pengganti Pada Anak Usia Dini". Saya menyadari bahwa tanpa bantuan dan bimbingan dari berbagai pihak sangatlah sulit bagi saya untuk menyelesaikan karya ini. Oleh karena itu, saya mengucapkan banyak terima kasih pada semua pihak yang telah membantu penyusunan buku ini. Sehingga buku ini bisa hadir di hadapan pembaca.

Dalam buku ini membahas tentang pola asuh orang tua pengganti dalam menanamkan kemandirian dan kedisiplinan pada anak usia 4-6 tahun. Buku ini mendeskripsikan bentuk pengasuhan kakek dan nenek (grandparents) dalam menanamkan kemandirian dan kedisiplinan anak usia 4-6 tahun, peran kakek dan nenek (grandparents) dalam menanamkan kemandirian dan kedisiplinan pada anak usia 4-6 tahun, proses pembentukan kemandirian dan kedisiplinan pada anak usia 4-6 tahun yang diasuh oleh kakek dan nenek dan pola asuh budaya setempat dalam menanamkan kemandirian dan kedisiplinan anak usia 4-6 tahun. Penulis menyadari bahwa buku ini masih jauh dari kesempurnaan.

Oleh karena itu kritik dan saran yang membangun sangat dibutuhkan guna penyempurnaan buku ini. Akhir kata saya berharap Tuhan Yang Maha Kuasa senantiasa berkenan membalas segala kebaikan semua pihak yang telah membantu.

Penulis 


\section{DAFTAR ISI}

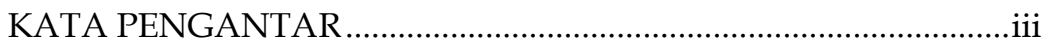

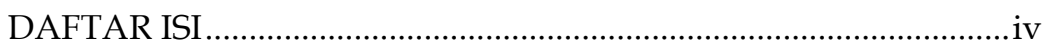

BAB I PENDAHULUAN ………………………………................. 1

A. Perkembangan Anak Usia Dini .......................................... 1

B. Pentingnya Pengasuhan Orang Tua....................................... 2

C. Budaya Pengasuhan Anak oleh Kakek dan Nenek (Grandparents) …….......................................................... 5

BAB II KEMANDIRIAN ANAK ....................................................... 10

A. Pengertian Kemandirian Anak ....................................... 10

B. Bentuk-bentuk Kemandirian Anak .................................... 13

C. Macam-macam Cara dalam Menanamkan Kemandirian pada Anak..................................................... 15

D. Faktor-faktor yang Mendorong terbentuknya Kemandirian Anak ............................................................ 16

E. Karakteristik Kemandirian Anak Usia Dini ...................... 17

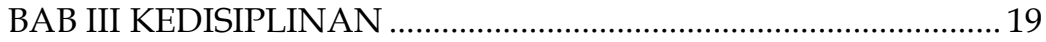

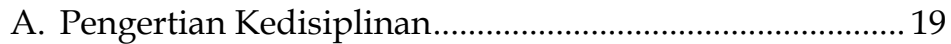

B. Bentuk-bentuk Kedisiplinan Anak ..................................... 20

C. Macam-macam Cara dalam Menanamkan Kedisiplinan Pada Anak ................................................... 22

D. Faktor-faktor yang Mendorong terbentuknya Kedisiplinan Anak ............................................................ 23

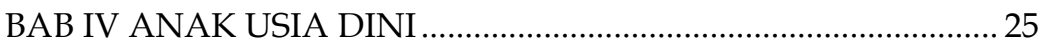

A. Pengertian Anak Usia Dini ................................................ 25

B. Karakteristik Anak Usia Dini ............................................ 26

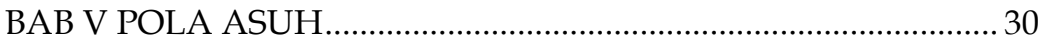

A. Pengertian Pola Asuh ..................................................... 30

B. Pengasuhan kakek dan nenek (Grandparents) ................... 33

C. Bentuk-bentuk Pola Asuh.................................................... 36

D. Faktor-faktor yang Mempengaruhi Pola Asuh................. 40

BAB VI POLA ASUH DALAM MEMBENTUK

KEMANDIRIAN DAN KEDISIPLINAN ….......................... 43

A. Bentuk Pengasuhan Kakek dan nenek Dalam

Menanamkan Kemandirian dan Kedisiplinan Anak Usia 4-6 Tahun. 
B. Peran Kakek dan nenek dalam Menanamkan

Kemandirian dan Kedisiplinan pada Anak Usia 4-6

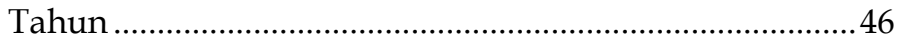

C. Proses Pembentukan Kemandirian dan Kedisiplinan

Pada Anak Usia 4-6 Tahun.................................................49

D. Pola Asuh Budaya Setempat dalam Menanamkan

Kemandirian dan Kedisiplinan pada Anak Usia 4-6

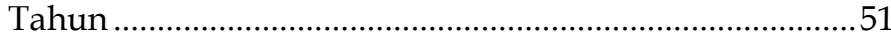

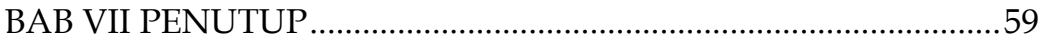

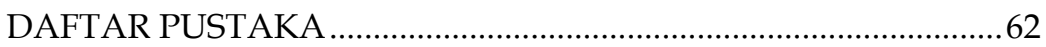

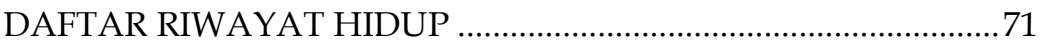




\section{POLA ASUH ORANG TUA PENGGANTI PADA ANAK USIA DINI}




\section{BAB I \\ PENDAHULUAN}

\section{A. Perkembangan Anak Usia Dini}

Anak usia dini merupakan salah satu modal dasar yang sangat berharga untuk menghasilkan sumber daya manusia yang berkualitas. Oleh karena itu, perlu dipersiapkan sejak dalam kandungan agar kelak menjadi sumber daya manusia yang berkualitas, sehat, bermoral, dan berguna bagi masyarakat melalui pengasuhan yang baik (Hasnida, 2015). Pada masa ini sering disebut sebagai masa keemasan (golden age) karena anak mengalami masa pertumbuhan dan perkembangan yang sangat pesat. Santrock (2015) mengatakan bahwa anak usia 4-6 tahun perkembangan otak hampir seperti orang dewasa, sehingga berpengaruh dalam merespon berbagai informasi yang diterima dari lingkungan. Masa ini merupakan masa yang paling tepat untuk melakukan pengembangan kemampuan fisik, bahasa, sosial-emosional, konsep diri, seni moral dan nilai-nilai agama serta kemandirian pada anak (Wiyani, 2014).

Erikson dalam teori perkembangan psikososialnya membagi perkembangannya ke dalam empat tahap, salah satunya adalah tahap Autonomy VS Shame/Doubt dimana rasa kemandirian anak ditandai dengan kemerdekaan atau kebebasan anak untuk melakukan segala sesuatu yang diinginkan dengan caranya sendiri, memberi peluang untuk melakukan sendiri apa yang mereka ingin lakukan tanpa dikritik, akan menghindarkan mereka dari rasa bersalah dan malu (Morisson, 2016). Kemandirian seorang anak pada hakikatnya tidak bersifat tunggal tetapi jamak. Artinya, seseorang dikatakan mandiri tidak hanya dilihat dari satu aspek semata, tetapi juga dari aspek lain seperti fisik, sosial, emosional, moral dimana kemandirian merupakan pintu gerbang menuju kedewasaan seseorang. Menjadi dewasa artinya tidak sekedar tumbuh dan berkembang secara fisik, 
tetapi juga menjadi matang secara emosional, moral, dan juga mental.

Orang tua merupakan penyedia utama pengasuhan anak dan strategi, relasi dan interaksi mereka akan berdampak pada aspek perkembangan anak (Desai, Reece, dan ShakespearePellington, 2017). Artinya bahwa perkembangan anak tergantung pada kualitas pengasuh dari lingkungan sekitar anak. Mereka akan bertumbuh dan berkembang dengan baik dibawah kondisi pengasuhan yang optimal. Orang tua yang memiliki komitmen terhadap kesejahteraan anaknya dapat memiliki pengaruh yang sangat positif. Anak yang tinggal dengan ayah ibu akan lebih baik dibandingkan anak yang hanya tinggal dengan ibu saja atau hanya ayah saja maupun tinggal dengan pengasuh lainnya. Hal ini dikarenakan ayah dan ibu memiliki perannya masing-masing dalam mengasuh anak. Mengasuh anak tidak hanya dibebankan kepada tanggung jawab seorang ibu namun ayah dan ibu bersamasama dalam mengasuh anak (Tegariyani \& Santoso, 2018).

\section{B. Pentingnya Pengasuhan Orang Tua}

Pengasuhan yang baik adalah pengasuhan yang dilakukan oleh kedua orang tua dengan menanamkan nilainilai kehidupan pada anak. Kasmadi, (2013) mengatakan bahwa yang dimaksud dengan nilai adalah nilai moral dan nonmoral. Penanaman nilai-nilai moral yang sifatnya untuk diri sendiri maupun sosial dirinci pada sikap dan perilaku seperti jujur, toleran, perilaku disiplin, kerjasama, mandiri, dan sebagainya.Margaretha, Kurniah, Dharmayana, Sasongko, \& Lutfi, (2018) dalam penelitian mengatakan bahwa pengasuhan orang tua sangat penting dalam menanamkan kemandirian anak, orang tua harus lebih membuka pikiran dalam bersosialisasi, dekat dengan anak sebagai seorang sahabat dan memperhatikan segala kebutuhan anak, sehingga anak merasa dipenuhi dan diperhatikan oleh orang tua, dihargai dan menyenangkan. Pengasuhan orang tua harus sangat mendukung dan merupakan model kemandirian bagi anak dalam memecahkan masalah sesuai dengan kemampuan anak 
sehingga anak mempunyai potensi menjadi seseorang yang mandiri (Padilla-walker, Fraser, \& Harper, 2012).

Hal ini senada dengan hasil penelitian yang dilakukan oleh (Suparmi, Ekowarni, Adiyanti, \& Helmi, (2018)mengatakan bahwa pengasuhan orang tua terbukti menjadi mediator dalam mempengaruhi dan menanamkan kemandirian pada anak. Kemandirian pada anak tidak terjadi begitu saja melainkan ada stimulus dari pengasuhan dan orang tua maupun orang-orang yang berada di sekitar anak. Hasil penelitian oleh (Froiland, 2013) mengungkapkan bahwa orang tua seharusnya mengaplikasikan teknik pola asuh dengan mendukung kemandirian anak di lingkungan rumah. Orang tua bersedia memberikan contoh dan teladan tentang bagaimana mendukung kemandirian yang mana dapat digeneralisasikan untuk belajar dalam berbagai bidang kehidupan. Artinya bahwa kemandirian sangat penting dikembangkan pada anak sejak usia dini karena bekal kemandirian yang mereka dapatkan ketika kecil akan menanamkan mereka menjadi pribadi yang mandiri, cerdas, kuat, dan percaya diri ketika menginjak dewasa nanti, sehingga mereka akan siap menghadapi masa depan yang baik. Mengembangkan perilaku kemandirian pada anak harus dimulai dari lingkungan rumah. Peran orang tua dalam mendidik anak sangat penting bagi pengembangan kemandirian anak karena orang tua adalah sosok pribadi yang akan ditiru anak, orang tua yang akan menjadi model dalam pembentukan karakter mandiri anak.

Dalam melatih kemandirian anak tidak ada salahnya kita memberikan penghargaan kepada anak atas semua usaha yang telah dilakukannya. Kemandirian erat kaitannya dengan disiplin. Dengan mengajarkan disiplin kepada anak sejak dini, berarti telah melatih anak untuk bias mandiri di masa datang dimana kunci kemandirian anak. adalah sebenarnya ada ditangan orang tua dan guru. Disiplin yang konsisten dan bantuan dari orang tua dan guru untuk mengerjakan sesuatu sendiri pada masa yang akan datang akan menjadi bagian dari 
dirinya. Anak-anak yang tidak mandiri cenderung tidak percaya diri dan tidak mampu menyelesaikan tugas hidupnya dengan baik. Akibatnya, prestasi belajarnya mengkhawatirkan dan bergantung pada orang lain. Selain mempengaruhi kemandirian, pola asuh orang tua juga mempengaruhi kedisiplinan anak. Pola asuh orang tua adalah bagaimana cara orang tua dalam menanamkan kedisiplinan pada anak (Hasbullah, 2012). Posisi keluarga sangatlah penting dalam menentukan tingkat disiplin pada diri anak. Alberto, Cuervo, and Nieblas (2018) dalam penelitiannya menyatakan bahwa Posisi keluarga dan iklim keluarga sangatlah penting dalam menentukan tingkat kedisiplinan pada diri anak. Sedangkan (Alaazi et al., 2018) dalam penelitiannya menyatakan bahwa disiplin merupakan pengaruh yang dirancang oleh orang tua untuk membantu anak agar mampu menghadapi tuntutan dari lingkungan dengan tujuan dari disiplin anak adalah untuk menanamkan perilaku, nilai-nilai, dan budaya yang dapat diterima, keluarga dan individu, dengan perbedaan yang sering di ambil antara metode disiplin fisik dan non fisik. Dengan adanya disiplin dapat membantu anak menjadi pribadi yang baik dan berhasil dimasa depan(Longstreth, Brady, \& Kay, 2015) .

Berdasarkan observasi, banyak orang tua baik ayah maupun ibu menganggap bahwa tanggung jawab terbesar dalam pengasuhan adalah dengan memenuhi kebutuhan dan memberi fasilitas yang cukup bagi anak, sehingga yang lakukan oleh orang tua adalah mencukupi segala kebutuhan mereka dengan bekerja sepanjang hari atau bekerja di luar negeri (migrant worker) sehingga menyerahkan pengasuhan kepada keluarga. Oleh sebab itu, pengasuhan anak diserahkan kepada kerabat dekat, terutama oleh orang tua ibu atau orang tua ayah yang disebut sebagai nenek atau kakek (grandparents). Fenomena ini menjadikan orang tua tidak dapat terlibat langsung dalam proses pengasuhan anak. 


\section{Budaya Pengasuhan Anak oleh Kakek dan Nenek (Grandparents)}

Peristiwa ini terjadi di Kampung Hobobelu Desa Ekoroka Kecamatan Golewa Kabupaten Ngada Propinsi NTT. Hasil observasi awal penulis di lokasi, ditemukan beberapa keluarga di kampung tersebut pergi bekerja diluar negeri (migrant worker) sehingga pengasuhan anak dilimpahkan kepada keluarga terdekat, ada yang diasuh oleh paman dan bibi, kakek dan nenek serta kerabat dekat lainnya yang orang tua percaya. Dari hasil observasi dan wawancara, penulis memilih satu anak yang diasuh oleh kakek dan nenek yang mana memiliki karakteristik yang berbeda dengan yang lainnya. Perbedaan sikap yang menonjol yaitu anak yang diasuh oleh kakek dan nenek (grandparents) lebih terlihat mandiri dan disiplin dibandingkan dengan anak yang diasuh oleh orang tua sendiri, maupun paman dan atau bibi. Hal ini ,berbeda dengan hasil penelitian yang dilakukan oleh (Edwards, 2018), bahwa anak yang diasuh oleh kakek dan nenek (grandparents), memiliki sikap yang negatif dibandingkan dengan anak yang tinggal bersama dengan kedua orang tua.

Pengasuhan anak yang dilakukan oleh kakek dan nenek (grandparents) diakibatkan karena orang tua bekerja diluar negeri (migran worker) demi mencukupi kebutuhan keluarga. Sehingga pengasuhan anak sepenuhnya dilimpahkan kepada kakek dan nenek sejak anak berumur tiga tahun. Orang tua pergi bekerja ke luar negeri sebagai pekerja imigran bukan dengan sengaja meninggalkan tanggungjawab, akan tetapi karena tuntutan kebutuhan ekonomi yang harus dipenuhi. Kakek dan nenek yang sudah tua harus membagi waktu untuk mengasuh anak dan juga harus bekerja di ladang demi kehidupan sehari-hari. Namun hal ini, tidak membuat kakek dan nenek merasa lelah, karena kehadiran cucu di rumah membuat mereka merasa terhibur dan terbantu. Dalam hidup keseharian, kakek dan nenek membiarkan anak untuk mengatur dirinya sendiri seperti mandi dan makan sendiri, ke sekolah sendiri, ganti pakaian sendiri. Selain itu, orang tua 
pengganti juga memberikan jadwal aktivitas sehari-hari bagi anak seperti cuci piring, angkat air, sapu rumah. Orangtua pengganti juga membuat sebuah aturan lisan bagi anak, agar anak bisa hidup disiplin.

Dari hasil wawancara ditemukan bahwa dalam mengasuh anak kakek dan nenek tidak pernah bersikap manja pada anak melainkan dilakukan dengan tegas dan proporsional. Tegas disini bukan mengekang ruang gerak anak, tetapi untuk mengatur anak agar disiplin dan bisa bertanggungjawab terhadap orang tua dan dirinya sendiri. Pengasuhan kakek dan nenek (grandparents) tidak terlepas dari pandangan hidup wilayah dan budaya setempat dimana menurut kakek dan nenek (grandparents) bahwa mengasuh dengan mempertahankan pola-pola lama justru membuat anak lebih berhasil. Sejalan dengan pendapat Santrock bahwa pengasuhan dapat dipengaruhi budaya, etnisitas, dan status sosial ekonomi. Budaya memiliki nilai-nilai yang digunakan sebagai tolok ukur yang menentukan baik-buruk, boleh-tidak boleh, benar-salah dalam ekspresi perilaku anak (Fitria, 2016).

Breheny, Stephens, \& Spilsbury (2013) dalam penelitiannya mengatakan bahwa pengasuhan oleh kakek dan nenek (grandparents) tidak selamanya memiliki stigma negatif terhadap perkembangan anak, karena apabila kakek nenek mengasuh secara tegas maka anak pun akan berkembang sebagaimana mestinya diantaranya aspek kemandirian dan kedisiplinan. Dimana, kakek dan nenek membangun hubungan yang baik dan harmonis dengan cucu-cunya, tanpa ada batas. Hal ini hubungan cucu dan kakek-nenek digambarkan berdasarkan kepedulian kakek-nenek (grandparents) terhadap kebutuhan cucunya. Kakek dan nenek (grandparents) memantau dan menyeimbangkan tingkat interaksi yang tepat dengan cucu mereka.

Berdasarkan penelitian sebelumnya yang dilakukan oleh Statham, (2011), terdapat beberapa dampak negatif terhadap anak yang diasuh oleh kakek dan neneknya. Dampak negatif tersebut diantaranya adalah pada proses belajar anak, yaitu 
kurangnya kemampuan anak pada persiapan sekolah mereka seperti pemahaman warna, huruf, angka dan sebagainya, anak mencari perhatian dari guru-gurunya dan teman-temannya serta membuat kegaduhan dalam kelas. Artinya bahwa tidak adanya kehadiran kedua orang tua baik ayah maupun ibu, menjadikan anak tidak memiliki model utama dalam keluarga. Sehingga anak memperlihatkan perilaku mencari perhatian kepada guru-gurunya, teman-temannya, kakek dan nenek maupun orang lain.

Shakya, Usita, Eisenberg, Weston, \& Liles, (2012) menyatakan bahwa terdapat masalah-masalah yang dihadapi kakek dan nenek dalam mengasuh cucunya, mulai dari masalah di level intrapersonal hingga level masyarakat. Masalah tersebut diantaranya berkaitan dengan kesehatan dan usia kakek nenek, konflik pribadi yang sering muncul, kesulitan berinteraksi dengan sistem sekolah anak, dan lain sebagainya. Artinya bahwa usia kakek dan nenek yang semakin tua dan mengalami gangguan kesehatan, dapat mengganggu proses interaksi antara kakek nenek dan anak. Selanjutnya Belleau, (2013) hasil penelitiannya bahwa apabila dibandingkan dengan anak-anak yang tinggal bersama orang tua, anak-anak yang tidak tinggal bersama orang tua cenderung mengalami masalah kesehatan fisik, menderita depresi, kecemasan dan gangguan psikoaktif lainnya. Mereka memiliki masalah perilaku sosial, kurang berhasil di sekolah, putus sekolah, serta memiliki masalah dalam bersosialisasi.

Senada dengan hasil penelitian yang dilakukan oleh Beazley, Butt, dan Ball (2018) bahwa anak-anak yang ditinggalkan oleh orang tua terjerat dalam kecemasan masyarakat, emosional terganggu (Malu, tidak percaya diri, tidak disiplin dan tidak sejahtera), anak-anak menjadi mudah putus asa, takut dan tidak mandiri dalam melakukan aktivitas. Dalam bersosialisasi anak menjadi mudah marah, dan tidak mampu mengendalikan emosional yang ada dalam diri. Kemudian berkaitan dengan sikap anak, anak yang diasuh oleh kakek dan nenek cenderung suka membantah, suka berbohong, 
pemalas dan mental terganggu (Allen, Cisneros, \& Tellez, 2015). Namun, penelitian yang dilakukan oleh Tan, Buchanan, \& Griggs, (2009) justru membuktikan bahwa terdapat peran positif dari pengasuhan oleh kakek dan nenek bagi anak yang ditinggalkan oleh orang tua demi sebuah pekerjaan. Peran positif tersebut berkaitan dengan penyesuaian diri anak di kalangan remaja atau pertemanannya.

Selain itu, Statham, (2011) dalam hasil penelitiannya juga memaparkan bahwa terdapat dampak positif yang timbul dari pengasuhan kakek dan nenek yaitu beberapa tahun sejak kecil anak memiliki kosa kata yang lebih baik. Dampak-dampak yang terjadi disebabkan oleh berbagai alasan seperti kakek dan nenek yang mampu mengatur anak ketika bersama dengan kelompok bermainnya. Artinya bahwa anak dari orang tua merantau memiliki kognitif yang baik, sikap keberanian dalam menyelesaikan konflik dengan temannya, bertanggung jawab atas diri sendiri dan mandiri dalam mengerjakan tugastugasnya, serta sudah bisa mengenal terkait waktu bermain, waktu istirahat, waktu belajar dan waktu bekerja membantu kakek dan nenek (grandparents).

Penelitian oleh Gottzén \& Sandberg (2017), hasilnya bahwa anak-anak merasa bahagia ketika kakek dan nenek peduli dan memberikan respon positif ketika mereka ditinggalkan orang tua. Kakek dan nenek (grandparents) menciptakan lingkungan yang nyaman bagi anak. Artinya bahwa pengasuhan oleh kakek dan nenek (grandparents) memberikan nilai yang secara umum, yaitu kekeluargaan, cinta kasih, kenyamanan, kebaikan dan perawatan yang menyenangkan. Dalam hal ini pengasuhan yang dilakukan oleh kakek- nenek (grandparents) justru mampu menanamkan kemandirian dan kedisiplinan anak yang baik yaitu terlihat pada perilaku anak dalam kesehariannya di rumah seperti anak mengerjakan pekerjaan rumah sendiri tanpa ada pendampingan kakek dan nenek, anak mandi dan ganti pakaian sendiri, dan anak ke sekolah sendiri tanpa diantar oleh kakek dan nenek. 
Khususnya subjek pada kajian ini, menunjukkan adanya sikap mandiri dan disiplin yang sangat baik selama diasuh oleh kakek dan nenek. Anak tersebut memiliki sikap mandiri dan disiplin yang baik, dimana anak selalu melakukan pekerjaan rumah dengan baik tanpa bersandar pada kakek dan nenek. Anak kesekolah sendiri, mandi dan makan sendiri, ganti pakaian dan pakai sepatu sendiri. Setiap bangun pagi, anak tidak merepotkan kakek dan nenek, anak bangun pagi berdoa, dan merapikan tempat tanakurnya sendiri. anak juga membantu kakek dan neneknya untuk menyelesaikan pekerjaan-pekerjaan ringan yang ada di rumah. Berbeda dengan penelitian sebelumnya, yang menyatakan bahwa ketanakakhadiran orang tua akan berdampak negatif pada anak. Namun, dalam kajian ini, selain dampak negatif yang terlihat pada perkembangan anak, pengasuhan oleh kakek dan nenek juga memiliki dampak positif pada perkembangan anak. 


\section{BAB II \\ KEMANDIRIAN ANAK}

\section{A. Pengertian Kemandirian Anak}

Mandiri berasal dari kata diri, dimana setiap membahas kata mandiri tidak dapat dilepaskan dari pembahasan mengenai perkembangan diri itu sendiri. Mandiri adalah sikap dan perilaku yang tidak mudah bergantung pada orang lain dalam menyelesaikan tugas-tugas (Yamin \& Sanan 2010). Hal ini berarti, mandiri bagi anak sangat penting, dengan mempunyai sifat mandiri, anak tidak akan mudah bergantung pada orang lain. Mandiri (independent) adalah sikap dan perilaku yang tidak mudah tergantung pada orang lain dalam menyelesaikan tugas kemandirian berkembang melalui proses belajar yang dilakukan secara bertahap dan berulang-ulang mulai dari tahap awal perkembangan kapasitas sampai tahap perkembangan kemandirian yang sempurna (Fadlillah \& Khorida, 2014). Hal ini, menunjukan bahwa, individu yang mandiri selalu melatih diri untuk melakukan sesuatu sendiri tanpa bergantung pada orang lain.

Mandiri dapat diartikan sebagai tindakan individu dalam kondisi yang mandiri, tanggung jawab, kebebasan individu dalam memilih, dan kemampuan individu dalam memenuhi kehendak dan potensi melalui usaha dan keberadaan seseorang dalam tindakan dan pilihan (Koivula, Gregoriadis, \& Rautamies, 2017). Artinya bahwa seseorang yang mandiri mampu membuat pilihan sendiri dan bertanggung jawab atas pilihannya sendiri tanpa melibatkan orang lain. Mandiri adalah kondisi di mana seseorang dapat berdiri sendiri tanpa bergantung pada orang lain, dapat melakukan kegiatan mereka sendiri, dapat membuat keputusan mereka sendiri dalam tindakan, dan dapat berempati dengan orang lain, dan banyak aspek kemandirian yang dapat dikembangkan untuk anak mulai dari berurusan dengan situasi di lingkungan untuk berinteraksi dengan orang lain, sehingga 
anak dapat berpikir dan bertindak sendiri (Hasibuan \& Marlita, 2018).

Yamin \& Sanan (2010) menyatakan kemandirian merupakan kemampuan hidup yang utama dan salah satu kebutuhan sejak awal usianya. Menanamkan anak usia dini sebagai pribadi yang mandiri memerlukan proses yang dilakukan secara bertahap. Artinya bahwa semua usaha untuk membuat anak usia dini menjadi mandiri sangatlah penting agar anak dapat mencapai tahapan kematangan sesuai dengan usianya. Dalam menanamkan kemandirian anak usia dini tidaklah mudah haruslah dimulai sejak dini dengan membiarkan anak melakukan aktivitas seharian sendiri.

Kemandirian merupakan suatu kondisi mental yang penting (Mu'in, 2011). Artinya bahwa dengan kemandirian, seseorang bertanggung jawab terhadap dirinya dan memahami bahwa untuk mendapatkan sesuatu dibutuhkan proses. Sejalan dengan Hasibuan \& Marlita, (2018) dalam penelitiannya bahwa Kemandirian bukanlah suatu keterampilan yang muncul tibatiba tetapi perlu diajarkan dan dilatih secara terus menerus secara berkesinambungan sehingga menjadi kebiasaan bagi anak usia dini, karena jika anak tidak belajar secara mandiri sejak usia dini maka akan sangat mungkin bagi mereka merasa bingung bahkan mereka mungkin tidak tahu bagaimana untuk membantu diri mereka sendiri di masa dewasa.

Sejalan dengan Pendergast (2015) dalam penelitian mengatakan bahwa kemandirian

"Independence is very important in a person's life because with independence children can become more responsible in meeting their needs and foster self-confidence in children. A child who has a sense of independence will be able to adjust to the environment, and the environment of the child itself, and can overcome difficulties that occur. Independence can be interpreted as a free personality form of independence, not as a person without socialization but as self directed through environmental influences" 
Artinya bahwa Kemandirian sangat penting dalam kehidupan seseorang, karena dengan kemandirian anak dapat menjadi lebih bertanggung jawab dalam memenuhi kebutuhan mereka dan menumbuhkan kepercayaan diri pada anak-anak. Seorang anak yang memiliki rasa kemandirian akan dapat menyesuaikan diri dengan lingkungannya, dan lingkungan anak itu sendiri, dan dapat mengatasi kesulitan yang terjadi. Kemandirian dapat diartikan sebagai bentuk kepribadian yang bebas dari kemandirian, bukan sebagai orang tanpa sosialisasi tetapi diarahkan sendiri melalui pengaruh lingkungan.

Kemandirian akan berkembang apabila selalu mendapat stimulasi dengan pemberian latihan-latihan yang dilakukan secara terus-menerus dan dilakukan sejak dini, mengapa dilakukan sejak dini! Sebuah pepatah lama mengatakan kecil teranja-anja besar terbawa-bawa, ini artinya bahwa anak yang telah mendapat latihan kemandirian sejak usia dini maka anak akan mengalami perubahan dalam membina diri sendiri. Mengingat kemandirian akan banyak memberi dampak positif bagi perkembangan individu, maka sebaiknya kemandirian diajarkan sedini mungkin sesuai dengan tahapan kemampuannya (Rahma \& Utami, 2016). Untuk dapat mandiri seseorang membutuhkan kesempatan, dukungan, dan dorongan dari keluarga serta lingkungan di sekitarnya, agar dapat mencapai otonomi atas diri sendiri. Peran keluarga serta lingkungan di sekitar dapat memperkuat untuk setiap perilaku yang dilakukan.

Kemandirian anak merupakan kemampuan anak untuk melakukan kegiatan dan tugas sehari-hari sendiri atau dengan sedikit bimbingan, sesuai dengan tahap perkembangan dan kemampuan anak (Majid, 2012). Sejalan dengan Yamin dan Sanan, (2013) bahwa kemandirian anak adalah bagaimana anak belajar untuk mencuci tangan, makan, memakai pakaian, mandi, buang air kecil atau besar sendiri. Mustari, (2014) mengatakan bahwa anak tidak akan mampu mengembangkan kemandiriannya selama orang tua dan orang-orang di sekitarnya selalu berada di dekatnya untuk melindungi dan 
selalu membantu anak dalam melakukan aktivitasnya. Hal ini berarti bahwa orang yang berperilaku mandiri mempunyai kemampuan untuk melakukan aktivitas hariannya sendiri dan akan memecahkan sendiri masalah-masalah yang dihadapi tanpa harus mengharapkan bantuan orang lain.

Kemandirian anak merupakan ketika anak mampu mengatasi dirinya sendiri, melakukan pekerjaan sendiri (makan sendiri, berpakaian sendiri dan membuat pilihannya sendiri), mampu mengatasi masalah, memiliki inisiatif, memiliki rasa percaya diri, mengarahkan tingkah lakunya menuju kesempurnaan, memperoleh kepuasan dari usahanya, memiliki kontrol diri (mampu mengendalikan tindakan) (Kuhn, 2017). Dalam hal ini bahwa, seseorang dikatakan mandiri, ketika Ia mampu menjalankan tugas dan aktivitasnya sendiri tanpa melibatkan orang lain.

Green, (2018) mengemukakan bahwa "a child's growing independence is demonstrated through the manipulation of physical objects and spaces, providing a child with a sense of individuality". Kemandirian seorang anak tumbuh ditunjukan melalui manipulasi benda-benda fisik dan ruang memberikan anak rasa individualitas. Artinya bahwa seseorang yang mandiri memerlukan ruang khusus untuk dirinya. Hal ini dikarenakan anak sudah mulai mengeksplorasikan dirinya dengan melakukan aktivitas harian sendiri.

Berdasarkan beberapa pengertian di atas disimpulkan bahwa kemandirian adalah perilaku anak yang didasarkan adanya kebebasan dari pengaruh orang lain, meliputi kemampuan anak dalam mengambil inisiatif, mampu mengatasi masalah, bertanggung jawab, mengerjakan aktivitas harian secara rutin, seperti makan, memakai pakaian sendiri, mandi, merawat diri, bermain bersama teman, mudah bergaul, mau berbagi dan mampu mengendalikan emosi.

\section{B. Bentuk-bentuk Kemandirian Anak}

Kemandirian dalam perkembangannya memiliki tingkatan-tingkatan. Perkembangan kemandirian seseorang berlangsung secara bertahap sesuai dengan tingkat 